\title{
Pretreatment with the Micro-alga, Spirulina Platensis Ameliorates Cyclophosphamide -Induced Hematological, Liver and Kidney Toxicities in Male Mice
}

\author{
Sabry A. El-Naggar', Mahrous A. Ibrahim²,3, Hala G. El-Tantawi ${ }^{4,5}$ and Ismail M. Al-Sharkawi ${ }^{1,6}$ \\ 1 Zoology Department, Faculty of Science, Tanta University, Tanta, Egypt. \\ 2 Forensic Medicine \& Clinical Toxicology Department, Faculty of Medicine, Suez Canal University, Ismailia, Egypt. \\ 3 Forensic Medicine \& Clinical Toxicology Department, College of Medicine, Aljouf University, Sakaka, KSA. \\ 4 Zoology Department, Faculty of Science, Ain Shams University, Cairo, Egypt. \\ 5 Biology Department, College of Science, Imam Abdulrahman Bin Faisal University, Dammam, KSA. \\ 6 Faculty of Marine Sciences, King Abdulaziz University, Jeddah 21589, KSA.
}

All right received.

\begin{abstract}
Cyclophosphamide (CTX) is used for the treatment of tumors however, it has several side effects which led to failure of the liver functions and significant reduction in the white blood cells total number (W.B.Cs). Spirulina platensis extract (S. platensis) has been found to restore the count of W.B.Cs to normal level with antioxidant properties. The aim of this study is to determine the prophylactic effect of Spirulina extract on CTX-induced hematological, liver and kidney toxicities. Thirty-two male albino mice were divided into four groups ( 8 mice/group). The first group (G1) was served as a control, the second group (G2) had injected i.p with $200 \mathrm{mg} / \mathrm{kg}$ CTX and the third group (G3) had orally treated with $S$. platensis extract (1000 mg $/ \mathrm{kg} \mathrm{b.w.)} \mathrm{for} \mathrm{two} \mathrm{weeks} \mathrm{every} \mathrm{day.} \mathrm{Group}$ four (G4) had treated orally with $1000 \mathrm{mg} / \mathrm{kg}$ of S. platensis extract, and then injected with $200 \mathrm{mg} / \mathrm{kg}$ CTX once. Three days after CTX injection, mice were sacrificed and blood samples were collected for complete blood count analysis and biochemical liver and kidney parameters. Liver and kidney tissues were harvested for histological examinations. The results showed that the injection of CTX reduced the total W.B.Cs number and did not affect the red blood cells and hemoglobin or hematocrit levels. Treatment with $1000 \mathrm{mg} / \mathrm{kg} \mathrm{S}$. platensis prior CTX treatment for two weeks did not lead to a restoration of W.B.Cs. However, the pre-treatment with $S$. platensis (1000 $\mathrm{mg} / \mathrm{kg} / \mathrm{body}$ weight) ameliorated the hepatic and renal dysfunctions and decreases the hepatic and renal histological changes which induced by CTX. In summary, the treatment with $S$. platensis for two weeks before CTXinjection led to a significant protection on both of the liver and kidney organs in mice.
\end{abstract}

Keywords $\quad$ Spirulina platensis; Cyclophosphamide; Hematological; Biochemical; Histological alterations

\begin{abstract}
Introduction
Q pirulina platensis (blue-green alga), has abundant $\mathcal{N}$ protein content $(50-70 \%)$, vitamins, carbohydrates and some minerals (Belay et al., 1993). Spirulina has been used as a supplementary agent due to its therapeutic and nutritional properties (Sandhu and Shenoy, 2009). It is also used for cancer treatment, hypercholesterolemia and anti-inflammatory (Konícková et al., 2014). The phenolic compounds, phycocyanin (7\%), $\gamma$-linolenic acid and tocopherol in Spirulina may have antioxidant activity (Belay, 2002; Ray et al., 2007). According to its antioxidant potential, S. platensis has reno-protective effect in gentamicin-induced acute tubular necrosis and a protective potential against apoptotic cell death (Avdagić ${ }^{1}$ et al., 2008; Chu et al., 2010). The ethanolic extract of S. platensis was tested as antibacterial and antiviral by ElBaz et al., 2013. S. platensis has been found to improve spermatogenesis in rats after $\mathrm{Cd}$ exposure (Farag et al., 2016). Furthermore, it has a protective role in cyclophosphamide (CTX)-induced ovotoxicity in rats (Yener et al., 2013), nephrotoxicity and urotoxicity (Sinanoglu et al., 2012) and suppress the CTX-induced
\end{abstract}

lipid peroxidation (Ray et al., 2007) and protect the germ cell due to doxorubicin-toxicity in male rats (Sudha and Kavimani, 2011). S. platensis polysaccharide can probably accelerate the hematopoietic recovery in mice after chemotherapy by enhancing the endogenous cytokines secretion (Liu and Zhang, 2002). Spirulina has an effect on modulation of the host immune system through acting in a direct way on myeloid lineages and on natural killer (NK) cell. In addition it has a potential effect as cardioprotective agent (Hirahashi et al., 2002).

CTX is used alone or in combination with other chemotherapies to treat several human malignancies including lymphomas, leukemia, myeloma, lung cancer and breast cancer (Lori et al., 2010). CTX treatment led to myelosuppression manifested as a decrease of the peripheral blood cells (Salem et al., 2012). After CTX treatment, the hepatic cytochrome P450 converted it to 4hydroxy-CTX and then converted to phosphoramide mustard which prevent cell division and acrolein which induced toxic side effects on normal cells (Ludeman, 1999; Sun and Peng, 2008). Previous and recent 
researches have shown that hepatic toxicity could be induced by the therapeutic dose of CTX (El-Naggar et al., 2016). It has been demonstrated in previous studies that the oxidative stress induced after chemotherapy address the direct effect of the pre-treatment with $\mathrm{S}$. platensis on CTX-induced hematological, liver and kidney toxicities.

\section{Materials and methods}

2.1 Chemicals

The conventional chemotherapy cyclophosphamide (CTX) was purchased from (Sigma-Aldrich, St. Louis, MO, USA). S. platensis were purchased from the local pharmacy at Sakaka city, Aljouf, Kingdom of Saudi Arabia (KSA). Aspartate aminotransferase (AST), alkaline phosphatase (ALP), alanine aminotransferase (ALT), albumin, total protein, creatinine and urea kits were purchased from Doa El-Shamal Company in Sakaka City, KSA.

2.2 Mice

The mice were obtained from the College of Pharmacy, Aljouf University, KSA. Thirty-two (32) male Swiss albino mice aged between 6-8 weeks and weighing approximately $25 \mathrm{~g}$ each were used to run the experiments. The animals were housed in Biology Department, College of Science, Aljouf University, KSA. They were kept in clean plastic cages (8 mice/cage) in $12 \mathrm{~h}$ dark/light cycle under normal laboratory condition of temperature and humidity and fed with commercial rodent pellets. Furthermore, the anesthetic procedures and handling of animals complied with the ethical guidelines of the Aljouf University's Ethical Committee, Aljouf University, KSA.

2.3 Treatment protocol

The mice under the study were divided into 4 groups; 8 mice each. Group 1 (G1) was served as s control had received normal saline (300 ul/mouse) intragastric. Group 2 (G2) which had injected intraperitoneally (i.p.) with a single dose of CTX (200 $\mathrm{mg} / \mathrm{kg}$ b.w). This dose was given according to a previous study by El-Naggar et al. (2016). Group 3 (G3) had injected intragastric by $300 \mathrm{ul} /$ mouse of S. platensis (1000 mg/kg b.w.) for 15 days. Group 4 (G4) had injected intragastric by $\mathrm{S}$. platensis $(1000 \mathrm{mg} / \mathrm{kg} \mathrm{b.w.)}$ for 15 days followed by a single injection of CTX (200 $\mathrm{mg} / \mathrm{kg} \mathrm{b.w}$ ). Mice were sacrificed by ether anesthesia after 3 days post CTX injection and subjected to a complete necropsy. determination

2.4 Biochemical and Hematological parameters

To determine the hematological parameters, blood samples were collected from the orbital plexus to estimate the total count of red blood cells (R.B.Cs), hemoglobin content $(\mathrm{Hb} \mathrm{g} / \mathrm{dl})$, hematocrit (Hct\%), and the total count of white blood cells (W.B.Cs) by using auto hematology analyzer (BC-3200, Mindray, China). For biochemical analysis, were collected in heparinized glass tubes. Serum was separated from the blood samples by centrifugation at $3000 \mathrm{rpm}$ for $15 \mathrm{~min}$. ALT, AST and ALP were measured by commercial kits (Reitman and Frankel, 1957) . Total protein and albumin levels were estimated by Biuret method (Itzhaki and Gill, 1964). Serum creatinine and urea were administration could be alleviated by some antioxidant materials. In line with this, earlier studies reported the beneficial effects of antioxidants on CTX induced damage (Patra et al., 2012). In this study, we aimed to estimated using Randox diagnostic kits (Setlow and Setlow, 1972).

2.5 Determination of the liver and kidney

histopathological changes

Tissue specimens of liver and kidney were harvested and fixed in $10 \%$ formalin. Paraffin blocks were prepared after completing the tissue processing in different grade of alcohol and xylene. Sections $(5 \mu \mathrm{m})$ were prepared from paraffin blocks using microtome, stained with hematoxylin and eosin and observed under light microscope to examine gross cellular damage (Bancroft et al., 1996).

2.6 Statistical analysis

Statistical analysis was performed using SPSS version 22.0 software package (SPSS, Inc, an IBM Company, Chicago, Illinois). Numerical data obtained from each experiment were expressed as mean $\pm \mathrm{SD}$. One-way ANOVA test was used for estimation of statistical differences between groups. Statistical significance was defined as $\mathrm{P}<0.05$.

\section{Results}

3.1 Treatment with $1000 \mathrm{mg} / \mathrm{Kg}$ of S. platensis prior to CTX injection did not change R.B.Cs, Hct\% and $\mathrm{Hb}$ values

Administration of CTX in mice had no effect on the total counts of R.B.Cs, hemoglobin ( $\mathrm{Hb})$ and hematocrit $(\mathrm{Hct} \%)$ values after 3 days of injection. The value of the R.B.Cs had no significant differences ( $p>$ $0.05)$ in animals which was treated with $(200 \mathrm{mg} / \mathrm{kg})$ in a single dose of CTX in G2, as compared to their control (G1) $(8.60 \pm 0.14,9.04 \pm 0.93$, respectively). In group 4 (G4) which treated by S. platensis $(1000 \mathrm{mg} / \mathrm{kg} \mathrm{b.w.)} \mathrm{for}$ 15 days, followed by CTX injection, the values of R.B.Cs showed no significant difference $(p>0.05)$ when compared to the mice that treated with a single dose of CTX (G2) (8.80 $\pm 0.60,8.60 \pm 0.14$, respectively) (Table 1). In $\mathrm{G} 2$, the level of $\mathrm{Hb}$ and Hct \% had non-significant differences when compared to the control (G1) ( $p$ > 0.05). The level of $\mathrm{Hb}$ showed non-significant difference in G4 when compared with G2 (14.60 $\pm 1.20,14.40 \pm$ 0.58 , respectively, $\mathrm{p}>0.05)$. Also, the level of Hct \% showed no significant differences in G4 when compared with $\mathrm{G} 2(49.53 \pm 6.44,49.90 \pm 1.26$, respectively, $\mathrm{p}<$ $0.05)$. (Table 1)

3.2 Treatment with $1000 \mathrm{mg} / \mathrm{Kg}$ of S. platensis prior to CTX injection did not restore the total W.B.Cs into its normal level

Treatment of mice with S. platensis (1000 $\mathrm{mg} / \mathrm{kg}$ b.w.) for 15 days, prior CTX injection did not restore the level of the total number of W.B.Cs into their normal values, however it increases the platelets account. The total count of W.B.Cs was significantly decreased in mice injected with a single dose of CTX (G2) when compared to G1 and G3 $(4.75 \pm 1.59,9.27 \pm 2.06,8.46 \pm$ 0.62 , respectively, $\mathrm{p}<0.05)$. The total number of W.B.Cs showed no significant differences $(p>0.05)$ in $\mathrm{G} 4$ when compared to G2. The platelets count was significantly decreased in G2 when compared to G 1 ( $p<0.05$ ). The 
platelets counts were significantly increased in $\mathrm{G} 4$ when compared with G2 $(1161.75 \pm 188.04,852.50 \pm 189.21$, respectively, $\mathrm{p}<0.05)$ (Table 2$)$.

3.3 Pre-treatment with $\mathrm{S}$. platensis for 15 consecutive days mitigated liver and kidney toxicity induced by CTX

The effects of S. platensis pre-treatment on the levels of the serum ALT, AST, ALP, total protein and albumin following CTX injection are shown in Table 2. The present study showed a non-significant change ( $p>$ 0.05 ) in the levels of these parameters among the mice of (G1 and G3) which served as the negative and positive control groups. Serum ALT, AST and ALP activities were significantly increased $(168 \pm 1.2 \mathrm{U} / \mathrm{L}, 246.2 \pm 2.7$ $\mathrm{U} / \mathrm{L}, 177 \pm 1.7 \mathrm{U} / \mathrm{L}$, respectively) in all mice injected with CTX relative to the untreated control animals (29.1 $\pm 0.3,68.3 \pm 0.4$ and $88.8 \pm 1.3 \mathrm{U} / \mathrm{L}$, respectively, $\mathrm{P}<$ $0.05)$ with significant reduction of serum total protein and albumin $(6.51 \pm 0.45 \mathrm{~g} / \mathrm{dl}$ and $3.64 \pm 0.08 \mathrm{~g} / \mathrm{dl}$, respectively, $\mathrm{P}<0.05)$. Pre-treatment with $\mathrm{S}$. platensis significantly mitigated CTX toxicity and restored these parameters to normal ranges $(\mathrm{P}<0.05)$. The pretreated mice with S. platensis, showed significant decrease of the serum ALT, AST and ALP activities to $(45.3 \pm 3.12,89.6$ \pm 1.3 and $98.4 \pm 2.8 \mathrm{U} / \mathrm{L}$, respectively) compared with CTX-treated group, $(\mathrm{P}<0.05)$ and significantly increased the serum total protein and albumin to $(7.36 \pm 0.23,4.61$ \pm 0.22 , respectively) compared with CTX-treated group, ( $\mathrm{P}<0.05)$. The data clearly show that $\mathrm{S}$. platensis has a suppressive effect on CTX-induced hepatotoxicity in mice. As shown in table 2, serum creatinine, urea levels were significantly increased $(\mathrm{P}<0.05)$ following administration of CTX compared to the control group. However, treatment with S. platensis (1000 mg/kg b.w.)

Table 1: ANOVA one way statistical analysis of the effect of the treatment with S. platensis on some hematological parameters in the different groups under the experimental study

\begin{tabular}{|l|c|c|c|c|}
\hline Parameters & G1 & G2 & G3 & G4 \\
\hline R.B.Cs $\left(10^{6} / \mathrm{ul}\right)$ & $9.04 \pm 0.90$ & $8.6 \pm 0.14$ & $9.3 \pm 0.20$ & $8.8 \pm 0.60$ \\
\hline $\mathrm{Hb}(\mathrm{g} / \mathrm{dl})$ & $15.10 \pm 1.10$ & $14.4 \pm 0.58$ & $15.1 \pm 0.50$ & $14.6 \pm 1.20$ \\
\hline Hct\% & $51.60 \pm 1.20$ & $49.9 \pm 1.26$ & $50.8 \pm 1.10$ & $49.53 \pm 6.44$ \\
\hline W.B.Cs $\left(10^{3} / \mathrm{ul}\right)$ & $9.27 \pm 2.06$ & $4.75 \pm 1.59^{\mathbf{a}}$ & $8.46 \pm 0.62^{\mathbf{b}}$ & $5.2 \pm 2.20^{\text {ac }}$ \\
\hline Platelets $\left(10^{3}\right)$ & $1031.2 \pm 153.60$ & $852.5 \pm 189.20^{\mathbf{a}}$ & $1152.6 \pm 178.5^{\mathbf{b}}$ & $1161.75 \pm 188.04^{\mathbf{b}}$ \\
\hline
\end{tabular}

Data are mean \pm SD. G1: Control, G2: CTX (200 mg/kg) alone, G3: S. platensis (1000 mg/kg b.w.), G4: S. platensis (1000 mg/kg b.w.)/CTX; RBC: Red blood cells; Hb: Hemoglobin; Hct \%: Hematocrit value.WBC: White blood cell. a: statistical difference from the control (G1) group-significant if $p \leq 0.05$. b: statistical difference from the CTX alone (G2) group- significant if $p \leq 0.05$. c: statistical difference from the S. platensis(G3) group- significant if $p \leq 0.05$

Table 2: ANOVA one way statistical analysis of the effect of the effect of $S$. platensis administration on the liver and kidney functions parameter

\begin{tabular}{|l|c|c|c|c|}
\hline \multicolumn{1}{|c|}{ Parameters } & G1 & G2 & G3 & G4 \\
\hline AST ( U/L) & $68.3 \pm 0.4$ & $246.2 \pm 2.7^{\mathbf{a}}$ & $74.2 \pm 1.1^{\mathbf{b}}$ & $89.6 \pm 1.3^{\mathbf{b}}$ \\
\hline ALT (U/L) & $29.1 \pm 0.3$ & $168 \pm 1.2^{\mathbf{a}}$ & $34.3 \pm 2.5^{\mathbf{b}}$ & $45.3 \pm 3.12^{\mathbf{b}}$ \\
\hline ALP(U/L) & $88.8 \pm 1.3$ & $177 \pm 1.7^{\mathbf{a}}$ & $90.2 \pm 1.8^{\mathbf{b}}$ & $98.4 \pm 2.8^{\mathbf{b}}$ \\
\hline TP $(\mathrm{g} / \mathrm{dl})$ & $8.06 \pm 0.22$ & $6.51 \pm 0.45^{\mathbf{a}}$ & $6.75 \pm 0.21$ & $7.36 \pm 0.23^{\mathbf{b}}$ \\
\hline Alb. (g/dl) & $4.58 \pm 0.13$ & $3.64 \pm 0.08^{\mathbf{a}}$ & $4.50 \pm 0.19^{\mathbf{b}}$ & $4.61 \pm 0.22^{\mathbf{b}}$ \\
\hline S. Urea (mg/dl) & $122.33 \pm 5.1$ & $223.18 \pm 11.7^{\mathbf{a}}$ & $93.12 \pm 5.3^{\mathbf{b}}$ & $102.16 \pm 5.4^{\mathbf{a b}}$ \\
\hline S. Creatinine ( $\mathrm{mg} / \mathrm{dl})$ & $1.99 \pm 0.09$ & $2.81 \pm 0.20^{\mathbf{a}}$ & $2.00 \pm 0.03^{\mathbf{b}}$ & $2.05 \pm 0.04^{\mathbf{b}}$ \\
\hline
\end{tabular}

Data are mean \pm SD. G1: Control, G2: CTX alone, G3: S. platensis (1000 mg/kg b.w.), G4: S. platensis (1000 mg/kg b.w.)/CTX, CTX: Cyclophosphamide; AST: Aspartate transaminase, ALT: Alanine transaminase; ALP: Alkaline phosphatase .TP: Total protein; Alb.: Albumin; a: statistical difference from the control (G1) group- significant if $p \leq$ 0.05. b: statistical difference from the CXT alone $(G 2)$ group- significant if $p \leq 0.05$. $c$ : statistical difference from the $S$. platensis(G3) group- significant if $p \leq 0.05$

significantly showed enhancement in the recorded kidney 3.4 The treatment with S. platensis (1000 $\mathrm{mg} / \mathrm{kg} / \mathrm{bw}$ ) prior to CTX injection revealed more or less normal like hepatocytes

Examination of control liver sections showed hepatocytes radiating from the central vein (Fig. 1A). Liver sections treated with CTX showed degenerated nuclei were noticed (Fig. 1B). Also, the degeneration of the epithelial lining of the central vein was observed (Fig. 1B). On the other side, the treatment with low dose normal like hepatocytes with few cytoplasmic degeneration and accompanied with widening of some blood sinusoids (Fig. 1C). Treatment with low dose S. improvement in the tissue architecture (Fig. 1D). $(1000 \mathrm{mg} / \mathrm{kg} / \mathrm{wt})$ prior to CTX injection revealed more or less normal like architecture of the kidney.

Examination of kidney sections of control mice revealed the glomeruli surrounded with distal and proximal renal tubules (Fig. 2A). The sections of mice intertubular and malformed glomeruli were observed (Fig. 2B). Treatment with S. platensis $(1000 \mathrm{mg} / \mathrm{kg} / \mathrm{wt})$ revealed more or less like architecture of the kidney treatment with $\mathrm{S}$. platensis before CTX caused marked amelioration and improvement in the kidney architecture with slight widening of the renal tubules (Fig. 2D). 


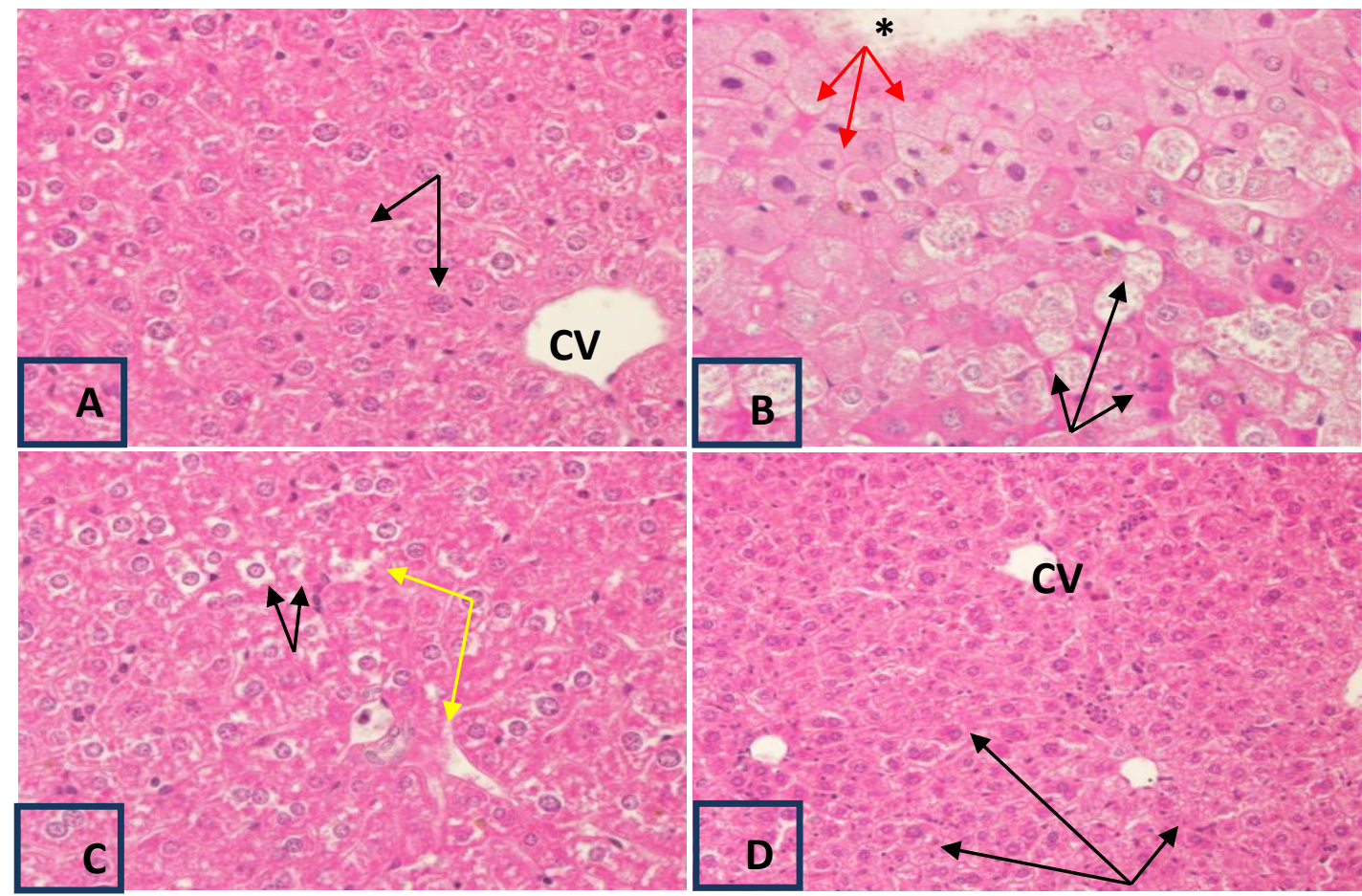

Fig. 1: Photomicrograph of liver sections stained with Hematoxylin \& Eosin from the different groups under the study. Fig. 1A: Control group showing the hepatocytes (arrows) radiating from the central vein (CV) (40X). Fig. 1B: CTX treated group showing highly degenerated hepatocytes (arrows), necrotic cells with pyknotic nuclei (red arrows) and intensive degeneration of the epithelial lining the central vein (stars) (100X). Fig. 1 C: $S$. platensis treated group showing more or less normal like hepatocytes with slight cytoplasmic degeneration surrounding the nuclei (arrows). Widening of some blood sinusoids (yellow arrows) was revealed (40X). Fig. 1D: Treatment with $S$. platensis followed by CTX treated group showing normal histological architecture of the liver (20X).
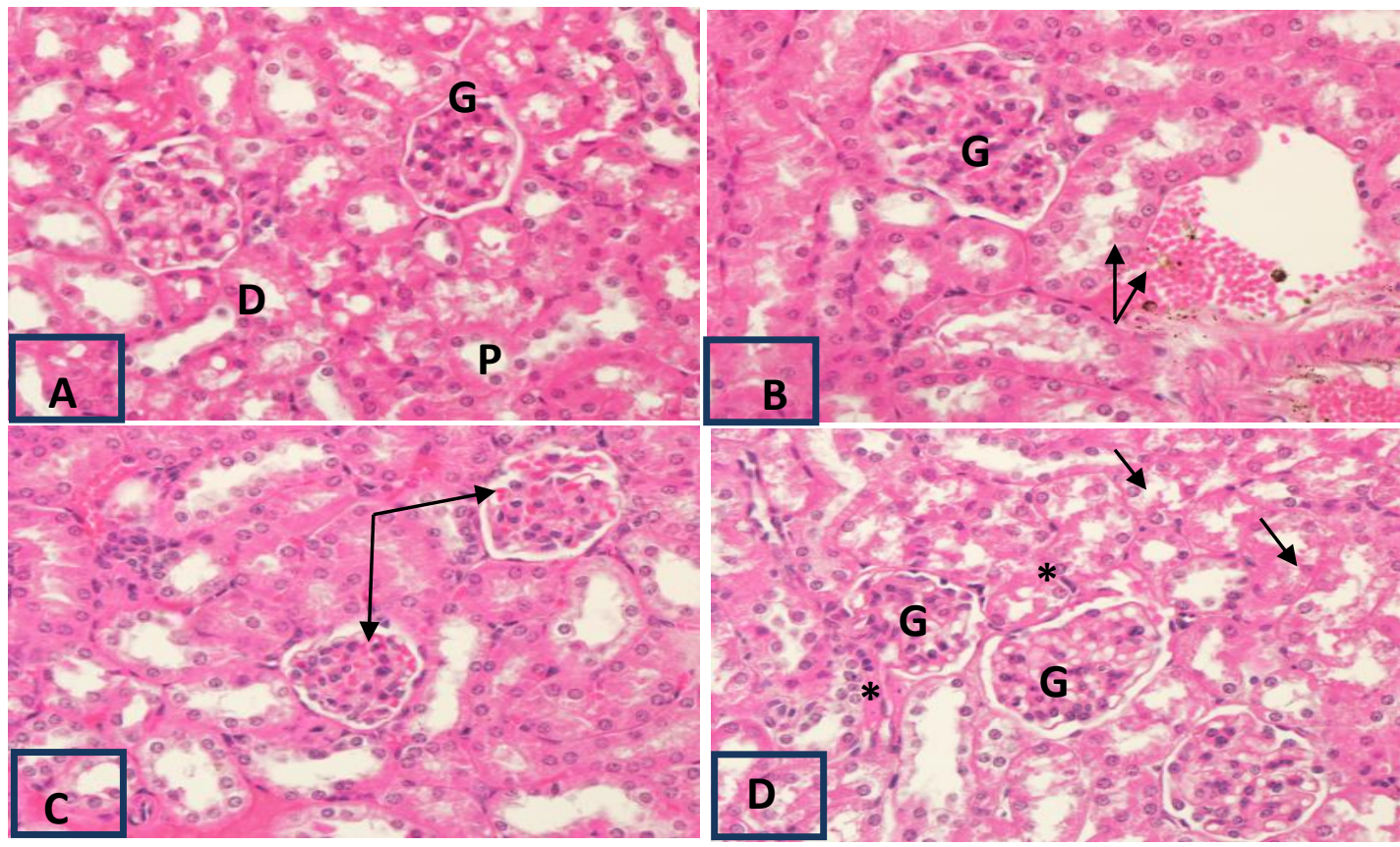

Fig. 2: Photomicrograph of kidney sections stained with Hematoxylin \& Eosin from the different groups under the study. Fig. 2A: control group showing normal glomeruli $(G)$, proximal (P) and distal (D) renal tubules (40X). Fig. 2B: CTX-treated group showing cellular infiltration at the intertubular spaces (arrows). Malformed enlarged glomerulus (G) was observed (40X). Fig. 2C: S. platensis treated group showing more or less normal like architecture. The glomeruli were displayed slight hemorrhage (arrows) (40X). Fig. 2D: Treatment with $S$. platensis followed by CTX- treated group showing disorganized glomeruli (G), widening of the renal tubules (stars) and degeneration of some epithelial lining (arrows) (40X). 


\section{Discussion}

Cyclophosphamide (CTX) is one of the most damaging alkylating agents that can cause oxidative stress due to the over-production of reactive oxygen species (ROS) (Alenzi et al., 2010). This study reported the potential prophylactic effects of $S$. platensis against hepatic and renal toxicity induced by CTX. The observed finding depicted that there is no significant difference in the total number of R.B.Cs, $\mathrm{Hb}$ and $\mathrm{Hct} \%$ in both groups of mice which treated with CTX alone and mice that were treated with CTX along with $S$. platensis. The current study showed that the total number of W.B.Cs in CTXinjected mice had significantly decreased comparing with the control group. Previous studies had revealed that neutropenia and lymphopenia resulted from the disturbance of hematopoietic cells division under the influence of chemotherapy treatment (Salem et al., 2012). According to the observation in our study, $S$. platensis did not enhance the restoration of W.B.Cs value in the pre- treated group with $S$. platensis before CTX and this is in disagreement with a previous study reported by Zhang et al.,2001.

Furthermore, the current results showed that the mice which were treated with $S$. platensis before CTX injection revealed that the total number of the platelets have been significantly increased comparing to the CTX-treated group. These findings depicted that $S$. platensis may display sturdy platelet activity in the same compliance with what is mentioned by Belay et al (Belay et al., 1993). Elevated plasma levels of alanine aminotransferase (ALT), aspartate aminotransferase (AST), alkaline phosphatase (ALP) enzymes by CTX are indicative of cellular damages and loss of functional hepatocyte membrane leading to their leakage into plasma (Kumar et al., 2005; Ibrahim et al., 2017). In the current study, the serum levels of AST, ALT, ALP, urea, and creatinine in the mice treated with CTX alone were significantly increased. These observations are in agreement with previous researches which reported that hepatic toxicity could be induced by CTX administration (Snover et al., 1989).

These values were significantly decreased in the mice that were treated with co- administration of CTX injection and S. platensis comparing to the mice that were injected with CTX alone, however, these values are still elevated when compared with the positive and negative control groups. This finding is in agreement with previous study which reported the hepatoprotective effects of $S$. platensis (Agrawal et al.,2013).

Furthermore, it depicts hepatic ameliorations properties through the reduction of lipoperoxidation products and the liver lipid profiles (El-Baky et al., 2009). Alam et al., (2013) have demonstrated in their research that the protective effects and immunestimulant activities of Spirulina against CTX - induced hepatic damage is attributed to the components of Spirulina which are superoxide dismutase enzyme, $\beta$ carotene, vitamins and selenium. These components explained the ability of Spirulina for inhibition of reaction involved in the formation of reactive metabolites and its radical scavenging activity which resulted in reduction of the hepatic enzymes levels (Alam et al., 2013).

Ferguson and Waikar, (2012) in their study have mentioned that the screening of cardiovascular or renal disorders could be done through measuring the plasma concentrations of urea and creatinine as they are considered the waste products of metabolism. CTX induced significant increase in plasma levels of creatinine and urea is an indication of abnormal renal function (Mouton and Holder, 2006). Peroxynitrite production which causes cell death in the renal tissue caused by intracellular ROS and nitric oxide production are activated by CTX derivative, acrolein (Korkmaz et al., 2007). The protective effect of S. platensis in correction of urea and creatinine levels in the mice treated with $S$. platensis before with CTX injection could be due to its content of $\beta$-carotene, enzyme superoxide dismutase (Alam et al., 2013).

In the present study, treating mice with CTX showed significant histological alterations in the liver including degenerated hepatocytes and necrotic cells with pyknotic nuclei alongside with the degeneration of the epithelial lining of the central vein was observed and in the kidney including cellular infiltration at the inter-tubular and malformed glomeruli. All these changes returned to normal picture in the S. platensis with CTX group.

Schwerdt et al., (2006) have revealed in their research that in the renal tissue, cell death in the proximal tubule epithelium could be induced by the acrolein and chloroacetaldehyde derived from CTX. Asiri, (2010) in another study showed that the tubular epithelium damage caused by the direct adverse effect of acrolein is the first cellular mechanisms for CTX toxicity and the increased production of free oxygen radicals through intracellular phosphoramide mustard, the principal alkylating metabolite of CTX is the second cause.

The adverse effects of CTX in the renal and hepatic tissue are significantly reversed as evidenced by the histopathological examination of the renal and hepatic tissue in the pretreatment group with Spirulina. These finding are in agreement with earlier studies (Sinanoglu et al., 2012).

The various components of this blue-green algae ( Spirulina) as vitamin E, chlorophyl, superoxide dismutase, B-complex vitamins, and numerous minerals and their protective and improving effects on oxidative stress and on apoptosis have long been studied widely (Chu et al., 2010; Marles et al., 2011).

\section{Conclusion}

According to this study, the pre-treatment with Spirulina before CTX injection did not return the number of W.B.Cs into their normal level, however, induced significant protection on the liver and kidney organs.

\section{Conflict of Interest}

\section{References}

The authors declare no conflict of interest.

Agrawal R, Soni K, Tomar JS et al., (2013): Review: Hepatoprotective activity of Spirulina species. 
International Journal of Scientific \& Engineering Research. 4(10), 1093-1101.

Alam MA, Haider N, Ahmed S et al., (2013): Tahlab (Spirulina) and few other medicinal plants having anti-oxidant \& immunomodulatory properties described in Unani medicine-a review. International Journal of Pharmaceutical Sciences and Research. 4(11):4158-4164.

Alenzi F, El-Bolkiny YE-S and Salem M (2010): Protective effects of Nigella sativa oil and thymoquinone against toxicity induced by the anticancer drug cyclophosphamide. British journal of biomedical science. 67(1):20-28.

Asiri YA (2010): Probucol attenuates cyclophosphamide-induced oxidative apoptosis, p53 and Bax signal expression in rat cardiac tissues. Oxid Med Cell Longev. 3(5):308-316.

Avdagić $^{1}$ N, Ćosović E, Nakaš-Ićindić ${ }^{1}$ E et al., (2008): Spirulina platensis protects against renal injury in rats with gentamicin-induced acute tubular necrosis. Bosnian Journal of Basic Medical Sciences. 8(4):331-336.

Bancroft J, Stevens A and Turner D (1996): Theory and practice of histological techniques 4th $\mathrm{Ed}$ Churchill Living Stone, New York Edinburgh. Madrid, Sanfrancisco.

Belay A (2002): The potential application of Spirulina (Arthrospira) as a nutritional and therapeutic supplement in health management. The Journal of the American Nutraceutical Association. 5(2):27-48.

Belay A, Ota Y, Miyakawa K et al., (1993): Current knowledge on potential health benefits of Spirulina. Journal of applied Phycology. 5(2):235-241.

Chu W-L, Lim Y-W, Radhakrishnan AK et al., (2010): Protective effect of aqueous extract from Spirulina platensis against cell death induced by free radicals. BMC Complement Altern Med. 10(1):53.

El-Baky HHA, El Baz F and El-Baroty GS (2009): Enhancement of antioxidant production in Spirulina platensis under oxidative stress. Acta physiologiae plantarum 31(3):623-631

El-Baz F, El-Senousy W, El-Sayed A et al., (2013); In vitro antiviral and antimicrobial activities of Spirulina platensis extract. Journal of Applied Pharmaceutical Science. 3(12):052-056.

El-Naggar SA, Abdel-Farid IB, Germoush MO et al., (2016): Efficacy of Rosmarinus officinalis leaves extract against cyclophosphamideinduced hepatotoxicity. Pharm Biol. 54(10): 2007-2016.

Farag MR, EL-Aziz RA, Ali H et al., (2016): Evaluating the ameliorative efficacy of Spirulina platensis on spermatogenesis and steroidogenesis in cadmium-intoxicated rats. Environmental Science and Pollution Research. 23(3):2454-2466.
Ferguson MA and Waikar SS (2012): Established and emerging markers of kidney function. Clin Chem 58(4):680-689.

Hirahashi T, Matsumoto M, Hazeki K et al., (2002): Activation of the human innate immune system by Spirulina: augmentation of interferon production and NK cytotoxicity by oral administration of hot water extract of Spirulina platensis. Int Immunopharmacol. 2(4):423-434.

Itzhaki RF and Gill D (1964): A micro-biuret method for estimating proteins. Analytical biochemistry. 9(4):401-410.

Ibrahim MA, Wani FA and Rahiman S (2017). Hepatoprotective effect of olive oil and camel milk on acetaminophen-induced liver toxicity in mice. International Journal of Medical Science and Public Health. 6(1):186-94.

Konícková R, Vanková K, Vaníková J et al. (2014): Anti-cancer effects of blue-green alga Spirulina platensis, a natural source of bilirubin-like tetrapyrrolic compounds. Ann Hepatol. 13:273-283.

Korkmaz A, Topal T and Oter S (2007): Pathophysiological aspects of cyclophosphamide and ifosfamide induced hemorrhagic cystitis; implication of reactive oxygen and nitrogen species as well as PARP activation. Cell Biol Toxicol. 23(5):303-312.

Kumar G, Sharmila Banu G, Kannan V et al., (2005): Antihepatotoxic effect of pcarotene on paracetamol induced hepatic damage in rats. Ind J Exp Biol. 43:351-355.

Liu X-m and Zhang H-q (2002): Effect of spirulina platensis polysaccharide on hematopoietic recovery and related cytokines in mice with transplanted tumor treated by chemotherapy. Chinese Journal of Integrated Traditional and Western Medicine. 8(2):130-133.

Lori J, Stein T and Thamm D (2010): Doxorubicin and cyclophosphamide for the treatment of canine lymphoma: a randomized, placebo- controlled study. Veterinary and comparative oncology. 8(3):188-195.

Ludeman SM (1999): The chemistry of the metabolites of cyclophosphamide. Curr Pharm Des. 5:627644.

Marles RJ, Barrett ML, Barnes J, et al., (2011): United States pharmacopeia safety evaluation of spirulina. Crit Rev Food Sci Nutr. 51(7):593604.

Mouton R and Holder K (2006): Laboratory tests of renal function. Anaesthesia \& Intensive Care Medicine. 7(7):240-243.

Patra K, Bose S, Sarkar S, et al., (2012): Amelioration of cyclophosphamide induced myelosuppression and oxidative stress by cinnamic acid. Chemico-biological interactions. 195(3):231-239.

Ray S, Roy K and Sengupta C (2007): In vitro evaluation of antiperoxidative potential of water extract of Spirulina platensis (blue green 
algae) on cyclophosphamide-induced lipid peroxidation. Indian J Pharm Sci. 69(2):190.

Reitman S and Frankel S (1957). A colorimetric method for the determination of serum glutamic oxalacetic and glutamic pyruvic transaminases. American journal of clinical pathology. 28(1): 56-63.

Salem ML, Al-Khami AA, El-Nagaar SA, et al. (2012); Kinetics of rebounding of lymphoid and myeloid cells in mouse peripheral blood, spleen and bone marrow after treatment with cyclophosphamide. Cellular immunology. 276(1):67-74.

Sandhu J and Shenoy S (2009): Efficacy of Spirulina Supplementation on Isometric Strength and Isometric Endurance of Quadriceps in Trained and Untrained Individuals-a comparative study. Ibnosina Journal of Medicine and Biomedical Sciences. 2(2):79-86.

Schwerdt G, Gordjani N, Benesic A, et al., (2006): Chloroacetaldehyde-and acrolein-induced death of human proximal tubule cells. Pediatr Nephrol. 21(1):60-67.

Setlow RB and Setlow JK (1972): Effects of radiation on polynucleotides. Annu Rev Biophys Bioeng. 1(1):293-346.

Sinanoglu O, Yener AN, Ekici S et al., (2012): The Protective effects of spirulina in cyclophosphamide induced nephrotoxicity and urotoxicity in rats. Urology. 80(6):1392-e1-6.

Snover DC, Weisdorf S, Bloomer J et al., (1989): Nodular regenerative hyperplasia of the liver following bone marrow transplantation. Hepatology. 9(3):443-448.

Sudha M and Kavimani S (2011):The protective role of spirulina on doxorubicin induced genotoxicity in germ cells of rats. International Journal of Pharma and Bio Sciences. (3) 2011

Sun H-X and Peng X-Y (2008): Protective effect of triterpenoid fractions from the rhizomes of Astilbe chinensis on cyclophosphamideinduced toxicity in tumor-bearing mice. J Ethnopharmacol. 119(2):312-317.

Yener NA, Sinanoglu O, Ilter E, et al. (2013): Effects of spirulina on cyclophosphamide-induced ovarian toxicity in rats: biochemical and histomorphometric evaluation of the ovary. Biochemistry research international

Zhang H-Q, Lin A-P, Sun Y et al., (2001): Chemo-and radio-protective effects of polysaccharide of Spirulina platensis on hemopoietic system of mice and dogs. Acta Pharmacol Sin. 22(12):1121-1124.

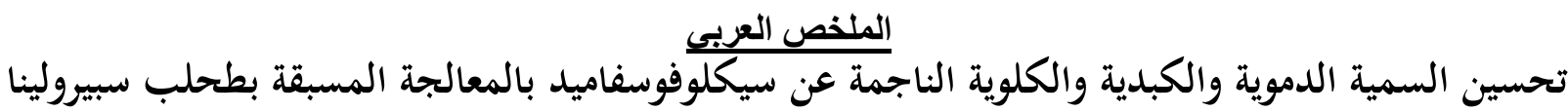 باتنسيس في ذكور الفئران}

\footnotetext{
صبري علي النجار' و و محروس عبدالباسط ابراهيمَr و هالة جلال محمد الطنطاوي؛،ه و اسماعيل مصطفى الشرقاوي 1، إن

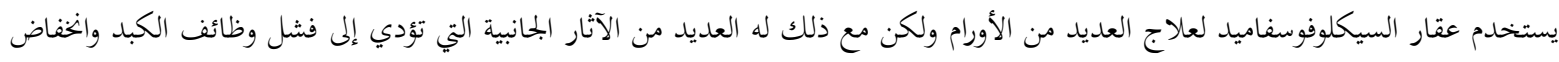
كبير في العدد الإجمالي لخلايا الدم البيضاء ـ وقد اثتت الدراسات المختلفة قدرة مستخلص سبيرولينا بلاتنسيس علي استعادة عدد خلايا الدم البيضاء إلى المستوى الطبيعي. ولذلك فان الهدف من هذه الدراسة هو تحديد التأثير الوقائي لمستخلص سبيرولينا قبل معالجة الفئران بعقار السيكلوفوسفاميد. تم تقسيم عدد

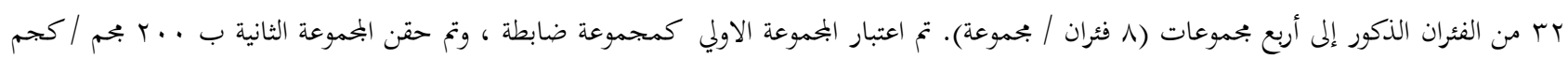

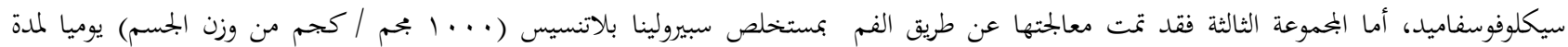

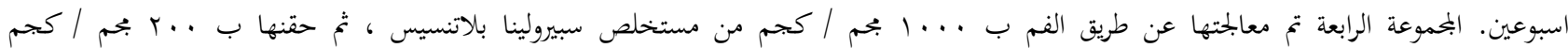

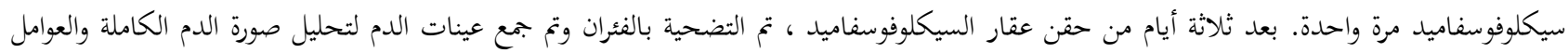
البيوكيميائية. ولفحص أنسجة الكبد والكلى. ولقد أظهرت النتائج أن حقن عقار السيكلوفوسفاميد ادي الي خفض عدد خلايا الدم البيضاء الكلية ولم يؤثر على عدد خلايا الدم الحمراء والهيموجلوبين أو مستويات الهيماتوكريت. العلاج مع . . . 1 بحم / كجم سبيرولينا بلاتنسيس قبل العلاج بسيكلوفوسفاميد لمدة

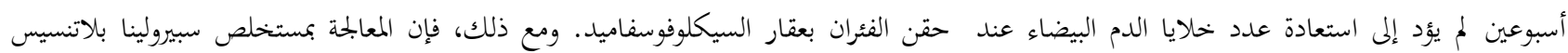
( . . . مبم / كجم / وزن الجسم) أدي الي تحسين الخلل الكبدي والكلوي ويقلل من التغيرات النسيجية الكبدية والكلية التي تسببها سيكلوفوسفاميد.

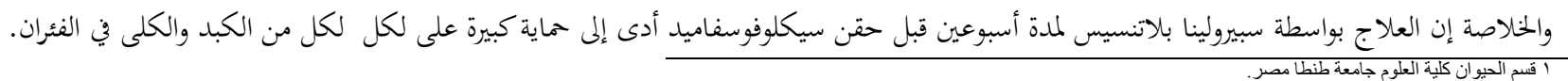

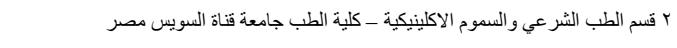

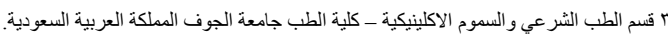

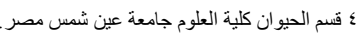

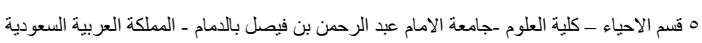
ا كلية علوم البحار جامعة الملك عبدالعزيز الملكة العربية السعودية.
} 